\title{
Intercropping of sunflower with Brachiaria brizantha cultivars during two sowing seasons in the interim harvest
}

\section{Consórcio do girassol com cultivares de Brachiaria brizantha em duas épocas de semeadura na safrinha}

\author{
Welma Santos Cruvinel $^{1}$; Kátia Aparecida de Pinho Costa ${ }^{2 *}$; Alessandro Guerra da \\ Silva $^{3}$; Eduardo da Costa Severiano ${ }^{2}$; Matheus Gonçalves Ribeiro ${ }^{4}$
}

\begin{abstract}
Intercropping of annual crops with tropical forages is an effective cultivation method to maximize grain production and pasture formation. The objective of this study was to evaluate the agronomic characteristics of sunflower and the productive and nutritional characteristics of Brachiaria brizantha cultivars grown with intercropping during two different sowing seasons in the interim harvest of the Center-West region of Brazil. The experiment was conducted in the municipality of Rio Verde, Goiás (GO), using a randomized block design with a $3 \times 2+4$ factorial scheme and three replicates per treatment. The following factors were tested: three Brachiaria brizantha cultivars (Marandu palisadegrass, Piata palisadegrass and Xaraes palisadegrass) grown with intercropping in the inter-row with the sunflower cultivar Charrua in two different sowing seasons (February and March); four additional treatments of sunflower; and the three tested Brachiaria brizantha cultivars grown in monoculture. Intercropping of sunflower with the Xaraes palisadegrass cultivar negatively affected the agronomic characteristics of sunflower, and intercropping with Marandu palisadegrass and Piata palisadegrass cultivars is recommended. Preference should be given to the Xaraes palisadegrass cultivar for forage production and to the Piata palisadegrass cultivar for the production of forage with higher nutritional value. Sowing in March led to the best sunflower agronomic characteristics, without affecting the productive and nutritional characteristics of the forages. Intercropping of sunflower with Brachiaria brizantha cultivars is therefore a promising cultivation method for the production of achenes and forage during the interharvest in the Center-West region of Brazil.
\end{abstract}

Key words: Helianthus annuus L. integrated crop-livestock systems.

\section{Resumo}

O consórcio de culturas anuais e forrageiras tropicais na mesma área tem-se mostrado como técnica de cultivo eficaz para maximizar a produção de grãos e formação de pastagens. Neste contexto, objetivou-se avaliar as características agronômicas do girassol, bem como as características produtivas e nutricionais de cultivares de Brachiaria brizantha consorciado com o girassol em duas épocas de semeadura, na safrinha na região Centro-Oeste. O experimento foi conduzido no município de Rio Verde-GO

I M.e em Ciências Agrárias, Agronomia, Instituto Federal Goiano, IFGoiano, Campus Rio Verde, Rio Verde, GO, Brasil. E-mail: welmacruvinel@hotmail.com

2 Profs., Programas de Pós-graduação em Ciências Agrárias e Zootecnia, IFGoiano, Campus Rio Verde, Rio Verde, GO, Brasil. E-mail: katia.costa@ifgoiano.edu.br; eduardo.severiano@ifgoiano.edu.br

3 Prof., Programa de Pós-graduação em Produção Vegetal, Universidade de Rio Verde, UniRV, Rio Verde, GO, Brasil. E-mail: silvaag@yahoo.com.br

4 Discente, Curso de Doutorado, Programa de Pós-Graduação em Zootecnia, Universidade Estadual de Maringá, UEM, Maringá, PR, Brasil. E-mail: matheus.ribeiro@zootecnista.com.br

* Author for correspondence

Received: Feb. 23, 2017 Approved: June 29, 2017 
no delineamento experimental em blocos ao acaso com três repetições em esquema fatorial $3 \times 2+4$, sendo três cultivares de Brachiaria brizantha (Marandu; Piatã e Xaraés) consorciadas na entrelinha com o cultivar de girassol Charrua em duas épocas de semeadura (fevereiro e março), além de quatro tratamentos adicionais referentes aos monocultivos do girassol e dos três cultivares de Brachiaria brizantha. Os resultados permitiram constatar que o consórcio do girassol com o capim-xaraés afeta negativamente as características agronômicas do girassol, sendo mais recomendando o consórcio com os capins marandu e piatã. Quando se objetiva a produção de forragem, deve-se dar preferência para o uso do capim-xaraés, e para obtenção de forragem de melhor valor nutricional, deve-se empregar o capim-piatã. A semeadura em março proporciona melhores resultados para características agronômicas do girassol, sem interferência nas características produtivas e nutricionais das forrageiras. Sendo assim, o consórcio de girassol com os cultivares de Brachiaria brizantha na safrinha mostrou-se como técnica de cultivo promissora para produção de aquênios e de forragem na entressafra na região Centro-Oeste.

Palavras-chave: Helianthus annuus L. integração lavoura-pecuária.

\section{Introduction}

Sunflower (Helianthus annuus L.) is one of the most widely grown oilseeds worldwide, both in terms of the cultivation area and production. Currently, it is classified as the second greatest source of raw material for edible oil production worldwide because of the excellent nutritional quality of its vegetable oil.

The sunflower crop has gained interest over the last few years because it is an alternative for production of raw materials for biofuels production (SANTOS et al., 2012). Similar to what occurs worldwide, sunflower production has been expanding in Brazil, with a cultivated area of 145.7 thousand hectares and production of 232.7 thousand tons in the 2013/2014 harvests (CONAB, 2014). The Center-West region of Brazil, where large companies are strategically located in the sunflower producing areas, represents $91 \%$ of national production.

The high water-use efficiency of sunflowers under water stress conditions and its tolerance to a wide range of temperatures, without affecting production, stimulate sunflower cultivation during the interim harvest, optimizing the use of farm infrastructure in the region (CASTRO; FARIAS, 2005).

Recently, sunflower intercropping with grasses from the genus Brachiaria has been adopted in integrated crop-livestock systems, promising results have been exhibited with the use of Brachiaria brizantha cv. Marandu, Brachiaria decumbens and Brachiaria ruziziensis (GONTIJO NETO et al., 2009; SOUZA et al., 2015).

With the appearance of new Brachiaria brizantha cultivars (Xaraes palisadegrass and Piata palisadegrass), there is a need to evaluate these materials in intercropping with sunflower. Identifying the association of Brachiaria brizantha cultivars with sunflower intercropping will allow for maximization of the production of achenes and forage in the inter-harvest (SILVA et al., 2007).

However, intercropping of sunflower with Brachiaria species has been studied very little, especially under interim harvest conditions. Therefore, there is a need for improved recommendations for planting and production in the agricultural systems of the Center-West region of Brazil, mainly in intercropping with forage grass (COSTA et al., 2016). Furthermore, the sunflower sowing season during the interim harvest influences achene production (SANTOS et al., 2012) due to the irregular distribution of rainfall and the occurrence of diseases following flowering (CASTRO; FARIAS, 2005). The objective of this study was to evaluate the agronomic characteristics of sunflower and the production and nutritional characteristics of Brachiaria brizantha cultivars grown with intercropping in two different sowing seasons during the interim harvest in the CenterWest region of Brazil. 


\section{Material and Methods}

The experiment was conducted in the field ( $17^{\circ} 48^{\prime} \mathrm{S}$; $50^{\circ} 55^{\prime} \mathrm{W}$; and $748 \mathrm{~m}$ altitude) in the Rio Verde municipality, Goiás (GO), during the 2013 interim harvest. The soil was a dystroferric Red Latosol. A soil sample was collected from the experimental area, from the $0-20 \mathrm{~cm}$ soil layer, and was used for soil physicochemical characterization. The soil characteristics were as follows: $510 \mathrm{~g} \mathrm{~kg}^{-1}$ clay; $160 \mathrm{~g} \mathrm{~kg}^{-1}$ silt, and $330 \mathrm{~g} \mathrm{~kg}^{-1}$ sand; $5.10 \mathrm{pH}$ in $\mathrm{CaCl}_{2} ; 2.88 \mathrm{cmol}_{\mathrm{c}} \mathrm{dm}^{-3} \mathrm{Ca} ; 1.27 \mathrm{cmol}_{\mathrm{c}} \mathrm{dm}^{-3} \mathrm{Mg} ; 0.01$ $\mathrm{cmol}_{\mathrm{c}} \mathrm{dm}^{-3} \mathrm{Al} ; 4.00 \mathrm{cmol}_{\mathrm{c}} \mathrm{dm}^{-3} \mathrm{Al}+\mathrm{H} ; 0.39 \mathrm{cmol}_{\mathrm{c}}$ $\mathrm{dm}^{-3} \mathrm{~K} ; 8.54 \mathrm{cmol}_{\mathrm{c}} \mathrm{dm}^{-3}$ cation exchange capacity (CEC); $8.72 \mathrm{~g} \mathrm{dm}^{-3} \mathrm{P} ; 3.4 \mathrm{~g} \mathrm{dm}^{-3} \mathrm{Cu} ; 1.5 \mathrm{~g} \mathrm{dm}^{-3} \mathrm{Zn}$; $43.0 \mathrm{~g} \mathrm{dm}^{-3} \mathrm{Fe}$ and $26.76 \mathrm{~g} \mathrm{dm}^{-3} \mathrm{OM}$. Rainfall and mean air temperature were monitored daily during the experiment (Figure 1).

Figure 1. Rainfall and air temperature recorded between January and November 2013 in Rio Verde, GO.
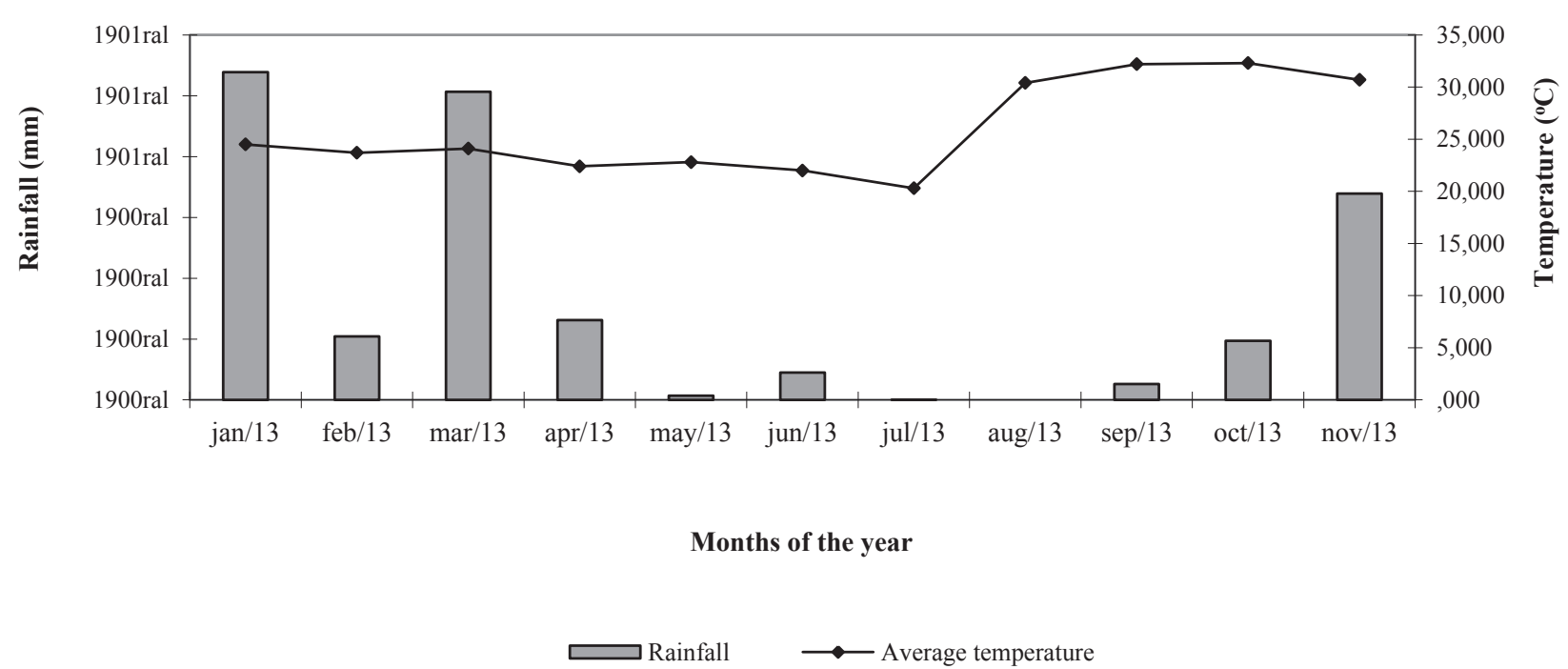

A randomized block design was used, with a $3 \times 2+4$ factorial scheme and three replicates per treatment. The tested factors included three Brachiaria brizantha cultivars (Marandu palisadegrass, Piata palisadegrass and Xaraes palisadegrass) grown with intercropping in interrow with the sunflower cultivar Charrua (triple hybrid, semi-precocious, with black achenes and high oil content), grown during two sowing seasons (February and March) and with four additional treatments of sunflower and three Brachiaria brizantha cultivars in monoculture.

Each plot consisted of eight 3.0-m-long rows spaced $0.50 \mathrm{~m}$ apart. During intercropping, the Brachiaria brizantha cultivars were sown into the sunflower inter-rows. The experimental area excluded one row on each side of each plot and 0.5 $m$ at each row end.

The experimentalareawaspreparedbyperforming weed desiccation, through the application of $150 \mathrm{~L}$ ha $^{-1}$ glyphosate $\left(720 \mathrm{~g}\right.$ ae ha- $\left.{ }^{-1}\right)$. Thirty days following desiccation, harrowing was performed using a disk plow for the elimination of weeds not controlled by the herbicide, followed by leveled harrowing due to intense infestation by guinea grass. One week before setting up the experiment, a second treatment of leveled harrowing was performed, and sowing furrows were opened with $0.50 \mathrm{~m}$ of inter-row space using a seeder. Furrows for sowing of Brachiaria brizantha cultivars in the sunflower inter-rows were 
opened manually, using hoes.

Sowings were performed on February $18^{\text {th }}$ and March $20^{\text {th }}$ using $80 \mathrm{~kg} \mathrm{ha}^{-1} \mathrm{P}_{2} \mathrm{O}_{5}$ and $20 \mathrm{~kg} \mathrm{ha}^{-1} \mathrm{FTE}$ BR 12 fertilizer, with $1.5 \mathrm{~kg}$ boron. During both the intercropping and monoculture experiment, sunflowers were sown at a $3 \mathrm{~cm}$ depth, and Brachiaria brizantha cultivars were sown at a $2 \mathrm{~cm}$ depth. Sunflower sowing was performed using six seeds per meter, and forage species were sown with $5 \mathrm{~kg}$ of pure viable seeds per hectare (SANTOS et al., 2016).

Sunflower plants were thinned 20 days after seedling emergence (DAE) in both the intercropping and monoculture treatments, leaving the equivalent of 60,000 plants ha ${ }^{-1}$. At $40 \mathrm{DAE}, 50 \mathrm{~kg} \mathrm{ha}^{-1}$ nitrogen as urea, $40 \mathrm{~kg} \mathrm{ha}^{-1} \mathrm{~K}_{2} \mathrm{O}$ as potassium chloride, and $1.5 \mathrm{~kg}$ boron in the form of boric acid were applied by broadcasting (SOUSA; LOBATO, 2012).

Following emergence, weed control was performed through weekly manual weeding until 45 DAE in both sowing seasons. Pest control was performed manually, at 70 DAE. Teflubenzurom at $1 \mathrm{~L} \mathrm{ha}^{-1}$ was applied to control the bordered patch (Chlosyne lacinia saundersii), and $1 \mathrm{~L} \mathrm{ha}^{-1}$ spinosad was applied to control the soybean looper (Pseudoplusia includens), with a spray liquid volume equivalent to $300 \mathrm{~L} \mathrm{ha}^{-1}$.

For sunflowers, the plant height (measured from the stem base to the capitulum insertion in ten plants selected randomly), stem diameter, and number of leaves per plant were quantified at 30 and $60 \mathrm{DAE}$, both in the intercropping and monoculture treatments. Plants were harvested manually at 125 DAE for the first sowing season and at 117 DAE for the second sowing season, when they had reached physiological maturity.

At harvest, the following parameters were evaluated in plants from the useful plot area: the plant height (measured from the stem base to the capitulum insertion), number of capitula, capitulum diameter (measured in ten plants selected randomly), dry weight (stems and leaves of all plants in the plot were collected and dry in an oven at $55^{\circ} \mathrm{C}$ to constant weight, following which the dry weight was determined and converted to $\mathrm{kg} \mathrm{ha}^{-1}$ ), the weight of 1000 achenes (1000 achenes were weighed in grams corrected to $13 \%$ moisture) and the achene yield (the capitulum were threshed and the achenes were weighed; the moisture was corrected to $13 \%$, and the values were converted to $\mathrm{kg} \mathrm{ha}^{-1}$ ) (SANTOS et al., 2016).

The achene oil content was determined through a chemical method, using hexane as an extractor. The oil yield was calculated by multiplying the achene oil content, in $\%$, by the achene yield, in $\mathrm{kg}$ ha $^{-1}$ (UCHÔA et al., 2011).

The dry weight production and nutritional value of Brachiaria brizantha cultivars were evaluated following the sunflower harvest until the beginning of the rainy season. The forages were evaluated in successive cuts. Samples with $1 \mathrm{~m}^{2}$ were collected using a quadrat positioned randomly within each plot, and the cuts were performed at a $20 \mathrm{~cm}$ height (SANTOS et al., 2016).

The first cut was performed at the sunflower harvest, on 06/20/2013 (first sowing season) and $07 / 13 / 2013$ (second sowing season), the second was performed 60 days after the first cut, on 08/20/2013 (first sowing season) and 09/12/2013 (second sowing season), and the third was performed 30 days following the second cut, on 09/20/2013 (first sowing season) and 10/08/2013 (second sowing season).

All of the plants in the experimental area were cut to the same height as the evaluated plants, and the resulting residue was removed from the area. A top-dressed fertilization was performed following the second cut, with an application of 80 $\mathrm{kg} \mathrm{ha}^{-1}$ nitrogen as urea and $40 \mathrm{~kg} \mathrm{ha}^{-1}$ potassium as potassium chloride (SOUSA; LOBATO, 2012).

The collected material was placed in plastic bags and taken to the laboratory. A representative sample 
of each plot, approximately $500 \mathrm{~g}$, was placed into a forced air oven at $55^{\circ} \mathrm{C}$ for pre-drying. The samples were ground using a Willey mill, with a 1-mmdiameter sieve, and were stored in plastic bags for subsequent analysis (SANTOS et al., 2016).

Bromatological analyses were performed to determine the dry mater $(\mathrm{DM})$, crude protein $(\mathrm{CP})$, neutral detergent fiber (NDF) and acid detergent fiber (ADF) according to Silva and Queiroz (2002). The in vitro dry matter digestibility (IVDMD) was determined according to Tilley and Terry (1963) and was adapted to an artificial rumen developed by $\mathrm{ANKON}^{\circledR}$, using an Ankom Technology Daisy incubator (in vitro true digestibility- IVTD). Rumen fluid collection was performed using two fistulated male steers with a $550 \mathrm{~kg}$ mean weight, with the animals kept grazing on $B$. brizantha cv. Marandu.

All of the evaluated parameters were subjected to analysis of variance followed by a Tukey's test, at $p<0.05$, using the software SISVAR 4.6 (FERREIRA, 2011).

\section{Results and Discussion}

\section{Sunflower cultivation}

The forage system $\mathrm{x}$ sowing season interaction had no effect $(\mathrm{p}>0.05)$ on the plant height (Table 1 ), stem diameter (Table 2), or number of leaves at 30 and 60 DAE (Table 3). However, main effects $(p<0.05)$ from the sowing season and forage system were observed on the stem diameter.

A higher plant height at $30 \mathrm{DAE}$ was observed during the March sowing season for all of the tested forage systems (Table 1). The lower plant development observed during the first sowing season may have been due to the irregular rainfall in February (Figure 1), with frequent droughts occurring at the beginning of seedling emergence, which is detrimental for plant development (SANTOS et al., 2002). Similar effects were observed at 60 DAE. The plant height was important for achene production because it was positively correlated with the production characteristics (TOMICH et al., 2003).

Table 1. The mean plant height of sunflowers grown in monoculture and in intercropping with Brachiaria brizantha cultivars during two different sowing seasons.

\begin{tabular}{|c|c|c|}
\hline \multirow{2}{*}{ Forage systems } & \multicolumn{2}{|c|}{ Sowing seasons } \\
\hline & February & March \\
\hline & \multicolumn{2}{|c|}{ Plant height at 30 DAE (cm) } \\
\hline Sunflower monoculture & $30.66 \mathrm{Ab}$ & $37.00 \mathrm{Aa}$ \\
\hline Sunflower x Marandu palisadegrass & $31.65 \mathrm{Ab}$ & $36.00 \mathrm{Aa}$ \\
\hline Sunflower x Piata palisadegrass & $30.00 \mathrm{Ab}$ & $37.65 \mathrm{Aa}$ \\
\hline Sunflower $\mathrm{x}$ Xaraes palisadegrass & $31.63 \mathrm{Ab}$ & $36.96 \mathrm{Aa}$ \\
\hline \multirow[t]{2}{*}{$\mathrm{CV} \%$} & \multicolumn{2}{|c|}{11.31} \\
\hline & \multicolumn{2}{|c|}{ Plant height at 60 DAE (cm) } \\
\hline Sunflower monoculture & $170.66 \mathrm{Ab}$ & $188.65 \mathrm{Aa}$ \\
\hline Sunflower x Marandu palisadegrass & $165.65 \mathrm{Ab}$ & $183.66 \mathrm{Aa}$ \\
\hline Sunflower x Piata palisadegrass & $170.66 \mathrm{Ab}$ & $181.00 \mathrm{Aa}$ \\
\hline Sunflower x Xaraes palisadegrass & $171.00 \mathrm{Ab}$ & $182.33 \mathrm{Aa}$ \\
\hline $\mathrm{CV} \%$ & & \\
\hline
\end{tabular}

Means followed by different upper case letters in the same column (forage systems) and lower case letters in the same row (sowing seasons) are significantly different according to a Tukey's test, at $p<0.05$. 
Was observed difference $(\mathrm{p}<0.05)$ in the stem diameter between forage systems in both sowing seasons in the two evaluations performed (Table 2 ). The lowest values were observed for sunflower from intercropping with all tested $B$. brizantha cultivars, and these were lower than those observed in monoculture (Table 2). Although significant differences in the plant height between intercropping and monoculture were not observed, the lower stem diameter of sunflowers from intercropping indicated competition between sunflower and $B$. brizantha in this cultivation system.

The sowing season only had a effect $(\mathrm{p}<0.05)$ on the stem diameter at $60 \mathrm{DAE}$, with higher values observed during the second season resulting from the higher sunflower development (Table 2). Higher stem diameter results in higher dry weight accumulation (GOMES et al., 2010) and decreased stalk lodging, thereby making crop handling and harvest easier (BISCARO et al., 2008).

Table 2. Mean stem diameter of sunflower grown in monoculture and in intercropping with Brachiaria brizantha cultivars in two different sowing seasons.

\begin{tabular}{lcc}
\hline \multirow{2}{*}{\multicolumn{1}{c}{ Forage systems }} & \multicolumn{2}{c}{ Sowing seasons } \\
\cline { 2 - 3 } & \multicolumn{1}{c}{ February } & March \\
\hline Sunflower monoculture & \multicolumn{2}{c}{ Stem diameter 30 at DAE (cm) } \\
Sunflower x Marandu palisadegrass & $1.23 \mathrm{Aa}$ & $1.20 \mathrm{Aa}$ \\
Sunflower x Piata palisadegrass & $1.00 \mathrm{Ba}$ & $1.04 \mathrm{Ba}$ \\
Sunflower x Xaraes palisadegrass & $1.03 \mathrm{Ba}$ & $1.06 \mathrm{Ba}$ \\
CV \% & $1.07 \mathrm{Ba}$ & $1.03 \mathrm{Ba}$ \\
& \multicolumn{2}{c}{ Stem diameter at 60 DAE (cm) } \\
Sunflower monoculture & $2.30 \mathrm{Ab}$ & $2.70 \mathrm{Aa}$ \\
Sunflower x Marandu palisadegrass & $2.06 \mathrm{Bb}$ & $2.55 \mathrm{Ba}$ \\
Sunflower x Piata palisadegrass & $1.99 \mathrm{Bb}$ & $2.53 \mathrm{Ba}$ \\
Sunflower x Xaraes palisadegrass & $1.89 \mathrm{Bb}$ & $2.48 \mathrm{Ba}$ \\
CV \% & \multicolumn{2}{c}{9.88} \\
\hline
\end{tabular}

Means followed by different upper case letters in the same column (forage systems) and lower case letters in the same row (sowing seasons) are significantly different according to a Tukey's test, at $p<0.05$.

The number of leaves in the first and second sowing season at 30 DAE was not influenced $(p>0.05)$ by the forage system or sowing season (Table 3). However, a effect $(\mathrm{p}<0.05)$ of the sowing season was observed at $60 \mathrm{DAE}$, with higher values observed during the March sowing season for all of the forage systems. The better rainfall distribution for this season (Figure 1), especially at the emergence of sunflower seedlings, resulted in more abundant leaf formation. The leaves are the main organ responsible for the accumulation of nutrients and organic compounds, which are translocated to the achenes (LIMA JÚNIOR et al., 2010), thereby producing higher achene yield and oil and crude protein contents (KARADOOAN; AKGÜN, 2009).

Intercropping with the Marandu palisadegrass and Piata palisadegrass cultivars did not affect $(p>0.05)$ the plant height at harvest during either sowing seasons, as no significant differences were observed 
between these two treatments and the sunflower monoculture (Table 4). This is consistent with the findings of Torres et al. (2008), who recommended $B$. brizantha cv. Piata for use in integrated croplivestock systems because its early growth is slower than that of the Marandu palisadegrass and Xaraes palisadegrass cultivars. However, intercropping with $B$. brizantha $\mathrm{cv}$. Xaraes decreased $(\mathrm{p}<0.05)$ the height of sunflower plants by 17 and $32 \%$ during the first and second sowing seasons, respectively. This may result from greater competition between B. brizantha cv. Xaraes and sunflower due to the wider leaves, faster growth, and high dry weight production of the Xaraes palisadegrass cultivar (FLORES et al., 2008). Similar results have been previously reported from February (SANTOS et al., 2012) and March sowings (BACKES et al., 2008).

Table 3. Mean number of leaves in sunflowers grown in monoculture and through intercropping with Brachiaria brizantha cultivars during two different sowing seasons.

\begin{tabular}{lcc}
\hline \multirow{2}{*}{\multicolumn{1}{c}{ Forage systems }} & \multicolumn{2}{c}{ Sowing seasons } \\
\cline { 2 - 3 } & \multicolumn{1}{c}{ Number of leaves at 30 DAE } \\
& \multicolumn{2}{c}{ March } \\
\hline Sunflower monoculture & $8.93 \mathrm{Aa}$ & $9.26 \mathrm{Aa}$ \\
Sunflower x Marandu palisadegrass & $8.86 \mathrm{Aa}$ & $8.06 \mathrm{Aa}$ \\
Sunflower x Piata palisadegrass & $8.46 \mathrm{Aa}$ & $8.80 \mathrm{Aa}$ \\
Sunflower x Xaraes palisadegrass & $8.50 \mathrm{Aa}$ & $8.40 \mathrm{Aa}$ \\
CV \% & \multicolumn{2}{c}{9.33} \\
\hline & \multicolumn{2}{c}{ Number of leaves at 60 DAE } \\
Sunflower monoculture & $16.83 \mathrm{Ab}$ & $25.03 \mathrm{Aa}$ \\
Sunflower x Marandu palisadegrass & $14.55 \mathrm{Ab}$ & $22.00 \mathrm{Aa}$ \\
Sunflower x Piata palisadegrass & $14.88 \mathrm{Ab}$ & $20.73 \mathrm{Aa}$ \\
Sunflower x Xaraes palisadegrass & $15.36 \mathrm{Ab}$ & $21.76 \mathrm{Aa}$ \\
CV \% & \multicolumn{2}{c}{14.51} \\
\hline
\end{tabular}

Means followed by different upper case letters in the same column (forage systems) and lower case letters in the same row (sowing seasons) are significantly different according to a Tukey's test, at $p<0.05$. 
Table 4. Mean plant height, number of capitula, capitulum diameter, and dry weight production at harvest in sunflowers grown in monoculture and grown with intercropping with Brachiaria brizantha cultivars during two different sowing seasons.

\begin{tabular}{|c|c|c|}
\hline \multirow{2}{*}{ Forage systems } & \multicolumn{2}{|c|}{ Sowing seasons } \\
\hline & February & March \\
\hline & \multicolumn{2}{|c|}{ Plant height (m) } \\
\hline Sunflower monoculture & $1.84 \mathrm{Ab}$ & $2.12 \mathrm{Aa}$ \\
\hline Sunflower x Marandu palisadegrass & $1.86 \mathrm{Ab}$ & $2.11 \mathrm{Aa}$ \\
\hline Sunflower x Piata palisadegrass & $1.85 \mathrm{Aa}$ & $2.08 \mathrm{Aa}$ \\
\hline Sunflower x Xaraes palisadegrass & $1.58 \mathrm{Ba}$ & $1.78 \mathrm{Ba}$ \\
\hline \multirow[t]{2}{*}{$\mathrm{CV} \%$} & \multicolumn{2}{|c|}{7.20} \\
\hline & \multicolumn{2}{|c|}{ Number of capitula } \\
\hline Sunflower monoculture & $3.23 \mathrm{Ab}$ & $5.03 \mathrm{Aa}$ \\
\hline Sunflower x Marandu palisadegrass & $3.16 \mathrm{Aa}$ & $4.90 \mathrm{Aa}$ \\
\hline Sunflower x Piata palisadegrass & $3.26 \mathrm{Aa}$ & 4.80 Aa \\
\hline Sunflower x Xaraes palisadegrass & $2.06 \mathrm{Ba}$ & $3.43 \mathrm{Ba}$ \\
\hline \multirow[t]{2}{*}{$\mathrm{CV} \%$} & \multicolumn{2}{|c|}{16.40} \\
\hline & \multicolumn{2}{|c|}{ Capitulum diameter (cm) } \\
\hline Sunflower monoculture & $16.20 \mathrm{Ab}$ & $19.43 \mathrm{Aa}$ \\
\hline Sunflower x Marandu palisadegrass & $14.76 \mathrm{Ab}$ & $18.36 \mathrm{Aa}$ \\
\hline Sunflower x Piata palisadegrass & $14.70 \mathrm{Ab}$ & $18.50 \mathrm{Aa}$ \\
\hline Sunflower x Xaraes palisadegrass & $13.90 \mathrm{Bb}$ & $15.96 \mathrm{Ba}$ \\
\hline \multirow[t]{2}{*}{$\mathrm{CV} \%$} & \multicolumn{2}{|c|}{9.28} \\
\hline & \multicolumn{2}{|c|}{ Dry weight production (kg ha $\left.{ }^{-1}\right)$} \\
\hline Sunflower monoculture & $2.573 \mathrm{Ab}$ & $3.173 \mathrm{Aa}$ \\
\hline Sunflower x Marandu palisadegrass & $2.393 \mathrm{Ab}$ & $3.040 \mathrm{Aa}$ \\
\hline Sunflower x Piata palisadegrass & $2.480 \mathrm{Ab}$ & $3.133 \mathrm{Aa}$ \\
\hline Sunflower x Xaraes palisadegrass & $1.753 \mathrm{Bb}$ & $2.206 \mathrm{Ba}$ \\
\hline $\mathrm{CV} \%$ & & \\
\hline
\end{tabular}

Means followed by different upper case letters in the same column (forage systems) and lower case letters in the same row (sowing seasons) are significantly different according to a Tukey's test, at $p<0.05$.

Intercropping of sunflowers with $B$. brizantha cv. Xaraes had a negative effect $(\mathrm{p}<0.05)$ on the number of capitula and the capitulum diameter during the two sowing seasons (Table 4). This indicates that the Xaraes palisadegrass cultivar was not indicated for intercropping with sunflowers because it is more aggressive and taller than the Marandu palisadegrass and Piata palisadegrass cultivars, with a detrimental effect on sunflowers. However, no significant difference was observed between sunflowers grown in monoculture and from intercropping with the Marandu palisadegrass and Piata palisadegrass cultivars.

Larger capitulum diameters in all of the tested forage systems and the number of capitula in sunflowers grown in monoculture were observed from the March sowing. This was due to the limited water availability at the initial stage of plant development that occurred from the February sowing, compromising the stand and consequently 
the number of capitula at harvest (SOUZA et al., 2014).

The sunflower water needs were met with between 400 and $500 \mathrm{~mm}$ of water. However, watering must be well distributed throughout the crop's life cycle (CASTRO; FARIAS, 2005). In this study, there was more rainfall during the crop cycle. However, the rainfall distribution was irregular, especially during the crop's early development, which affected its establishment and development. The results obtained for the March sowing were similar to the ones reported by Tomich et al. (2003) for interim harvest conditions and were higher than reported by Capone et al. (2011) for sunflower sowing on March $15^{\text {th }}$ in the Cerrado in Tocantins.

Similar to the observations of capitulum height and number of capitula, lower dry weight production was observed for sunflower intercropped with $B$. brizantha $\mathrm{cv}$. Xaraes during both sowing seasons (Table 4), which confirms the competition between the two species. A higher dry weight may result in higher biomass at the soil surface, resulting in greater moisture retention in the soil. Nevertheless, the decomposition of leaves and sunflower capitula occurs quickly because they have low $\mathrm{C} / \mathrm{N}$ ratios; however, the opposite is true for the stem (LOBO et al., 2012). Therefore, the March sowing exhibited higher dry weight production, favored by better rainfall distribution.

The yield and weight of 1000 achenes were similar $(p>0.05)$ between the monoculture and intercropping with the $B$. brizantha cultivars Marandu palisadegrass and Piata palisadegrass (Table 5). During intercropping with $B$. brizantha cv. Xaraes, there was a decrease $(p<0.05)$ in the achene yield and weight of 1000 achenes (22 and $44 \%$ and 25 and $34 \%$ for the February and March sowings, respectively), confirming competition between this cultivar and sunflower as previously discussed for the other variables.

The yield and weight of 1000 achenes was higher in the March than February sowing (Table 5). Rainfall occurred until the end of June for the March sowing season $(44.8 \mathrm{~mm})$, which favored achene production (CASTRO; FARIAS, 2005). The achene yield in the first sowing season was similar to that obtained by Backes et al. (2008), with 1.861 $\mathrm{kg} \mathrm{ha}^{-1}$ yield during an interim harvest, and higher than those by Capone et al. (2011), with 890.8 and $773.4 \mathrm{~kg} \mathrm{ha}^{-1}$ mean yields for sowings performed on $03 / 15 / 2009$ and $03 / 28 / 2009$, respectively. 
Table 5. Mean achene yield, weight of 1000 achenes, oil content, and yield of sunflowers grown in monoculture and in intercropping with Brachiaria brizantha cultivars during two different sowing seasons.

\begin{tabular}{|c|c|c|}
\hline \multirow{2}{*}{ Forage systems } & \multicolumn{2}{|c|}{ Sowing seasons } \\
\hline & February & March \\
\hline & \multicolumn{2}{|c|}{ Achene yield (kg ha $\left.{ }^{-1}\right)$} \\
\hline Sunflower monoculture & $1.971 \mathrm{Ab}$ & $2.802 \mathrm{Aa}$ \\
\hline Sunflower x Marandu palisadegrass & $1.882 \mathrm{Ab}$ & $2.919 \mathrm{Aa}$ \\
\hline Sunflower x Piata palisadegrass & $1.994 \mathrm{Ab}$ & $3.133 \mathrm{Aa}$ \\
\hline Sunflower $\mathrm{x}$ Xaraes palisadegrass & $1.591 \mathrm{Bb}$ & $2.045 \mathrm{Ba}$ \\
\hline \multirow[t]{2}{*}{$\mathrm{CV} \%$} & \multicolumn{2}{|c|}{19.74} \\
\hline & \multicolumn{2}{|c|}{ Weight of 1000 achenes (g) } \\
\hline Sunflower monoculture & $24.35 \mathrm{Ab}$ & $47.56 \mathrm{Aa}$ \\
\hline Sunflower x Marandu palisadegrass & $23.17 \mathrm{Ab}$ & $48.82 \mathrm{Aa}$ \\
\hline Sunflower x Piata palisadegrass & $24.14 \mathrm{Ab}$ & $46.04 \mathrm{Aa}$ \\
\hline Sunflower x Xaraes palisadegrass & $19.02 \mathrm{Bb}$ & $35.31 \mathrm{Ba}$ \\
\hline \multirow[t]{2}{*}{$\mathrm{CV} \%$} & \multicolumn{2}{|c|}{16.68} \\
\hline & \multicolumn{2}{|c|}{ Oil content $(\%)$} \\
\hline Sunflower monoculture & $37.33 \mathrm{Aa}$ & $47.00 \mathrm{Ab}$ \\
\hline Sunflower x Marandu palisadegrass & $36.70 \mathrm{ABa}$ & $46.33 \mathrm{Aa}$ \\
\hline Sunflower x Piata palisadegrass & $35.90 \mathrm{ABa}$ & $47.35 \mathrm{Ab}$ \\
\hline Sunflower x Xaraes palisadegrass & $33.65 \mathrm{Ba}$ & $38.62 \mathrm{Ba}$ \\
\hline \multirow[t]{2}{*}{$\mathrm{CV} \%$} & \multicolumn{2}{|c|}{11.30} \\
\hline & \multicolumn{2}{|c|}{ Oil yield $\left(\mathrm{t} \mathrm{ha}^{-1}\right)$} \\
\hline Sunflower monoculture & $0.735 \mathrm{Ab}$ & $1.316 \mathrm{Aa}$ \\
\hline Sunflower x Marandu palisadegrass & $0.690 \mathrm{Ab}$ & $1.352 \mathrm{Aa}$ \\
\hline Sunflower x Piata palisadegrass & $0.715 \mathrm{Ab}$ & $1.483 \mathrm{Aa}$ \\
\hline Sunflower x Xaraes palisadegrass & $0.535 \mathrm{Bb}$ & $0.789 \mathrm{Ba}$ \\
\hline $\mathrm{CV} \%$ & & \\
\hline
\end{tabular}

Means followed by different upper case letters in the same column (forage systems) and lower case letters in the same row (sowing seasons) are significantly different according to a Tukey's test, at $p<0.05$.

As observed for the achene yield, intercropping with the Xaraes palisadegrass cultivar resulted in decreased $(p<0.05)$ sunflower oil content and yields during both sowing seasons. No differences were observed for the remaining forage systems (Table 5). However, the regular rainfall distribution during the March sowing season resulted in a $25 \%$ increase in the oil content compared with the February sowing season. Results similar were reported by Lobo et al. (2012). Higher oil yields are important for biodiesel production (GAMA et al., 2010) in the Center-West region of Brazil, which favors sunflower cultivation in that region.

\section{Brachiaria brizantha cultivars}

Sunflower intercropping with Brachiaria brizantha cultivars resulted in a lower $(\mathrm{p}<0.05)$ plant height at 30 DAE (Table 6). At 60 and 90 DAE and at sunflower harvest, lower plant heights were only observed for cultivars Marandu palisadegrass and Piata palisadegrass when compared with 
monocultures in intercropping with sunflower during both sowing seasons. This may be because at $60 \mathrm{DAE}$, the sunflower plants had a larger leaf area, causing shading and consequently higher competition with the Marandu palisadegrass and Piata palisadegrass cultivars.

Planting sunflowers in a reduced space $(0.50$ $\mathrm{m}$ inter-rows) may have further contributed to the increased shading of these forage plants. For $B$. brizantha cv. Xaraes, the heights were similar under intercropping and monoculture (Table 6) due to the species' greater aggressiveness towards sunflower. Similar results were reported by Gontijo Neto et al. (2009), who observed less development of Xaraes palisadegrass, Piata palisadegrass and Panicum maximum cv. Massai in intercropping with sunflower.

The tallest heights at 60 and $90 \mathrm{DAE}$ and at sunflower harvest, for all forage systems, were observed from March sowing due to the better rainfall distribution, which favored the growth of the $B$. brizantha cultivars.

Table 6. Mean plant heights of Brachiaria brizantha cultivars grown in monoculture and in intercropping with sunflower during the two different sowing seasons.

\begin{tabular}{|c|c|c|}
\hline \multirow{2}{*}{ Forage systems } & \multicolumn{2}{|c|}{ Sowing seasons } \\
\hline & February & March \\
\hline & \multicolumn{2}{|c|}{ Plant height 30 DAE (cm) } \\
\hline Marandu palisadegrass in monoculture & $31.53 \mathrm{Aa}$ & $37.66 \mathrm{Aa}$ \\
\hline Piata palisadegrass in monoculture & $32.33 \mathrm{Aa}$ & $39.00 \mathrm{Aa}$ \\
\hline Xaraes palisadegrass in monoculture & $31.00 \mathrm{Aa}$ & $39.80 \mathrm{Aa}$ \\
\hline Sunflower x Marandu palisadegrass & $27.73 \mathrm{Ba}$ & $32.00 \mathrm{Ba}$ \\
\hline Sunflower $\mathrm{x}$ Piata palisadegrass & $28.00 \mathrm{Ba}$ & $30.33 \mathrm{Ba}$ \\
\hline Sunflower $\mathrm{x}$ Xaraes palisadegrass & $26.53 \mathrm{Ba}$ & $33.66 \mathrm{Ba}$ \\
\hline \multirow[t]{2}{*}{$\mathrm{CV} \%$} & \multicolumn{2}{|c|}{10.84} \\
\hline & \multicolumn{2}{|c|}{ Plant height 60 DAE (cm) } \\
\hline Marandu palisadegrass in monoculture & $59.50 \mathrm{Ab}$ & $96.63 \mathrm{Aa}$ \\
\hline Piata palisadegrass in monoculture & $67.90 \mathrm{Ab}$ & $98.16 \mathrm{Aa}$ \\
\hline Xaraes palisadegrass in monoculture & $70.96 \mathrm{Ab}$ & $108.33 \mathrm{Aa}$ \\
\hline Sunflower x Marandu palisadegrass & $38.10 \mathrm{Bb}$ & $45.36 \mathrm{Ba}$ \\
\hline Sunflower $\mathrm{x}$ Piata palisadegrass & $37.83 \mathrm{Bb}$ & $44.06 \mathrm{Ba}$ \\
\hline Sunflower x Xaraes palisadegrass & $59.83 \mathrm{ABb}$ & $79.80 \mathrm{Aba}$ \\
\hline \multirow[t]{2}{*}{$\mathrm{CV} \%$} & \multicolumn{2}{|c|}{14.75} \\
\hline & \multicolumn{2}{|c|}{ Plant height 90 DAE (cm) } \\
\hline Marandu palisadegrass in monoculture & $75.50 \mathrm{Ab}$ & $106.62 \mathrm{Aa}$ \\
\hline Piata palisadegrass in monoculture & $87.90 \mathrm{Ab}$ & $110.10 \mathrm{Aa}$ \\
\hline Xaraes palisadegrass in monoculture & $90.96 \mathrm{Ab}$ & $128.50 \mathrm{Aa}$ \\
\hline Sunflower x Marandu palisadegrass & $58.50 \mathrm{Bb}$ & $75.35 \mathrm{Ba}$ \\
\hline Sunflower x Piata palisadegrass & $53.30 \mathrm{Bb}$ & $74.40 \mathrm{Ba}$ \\
\hline Sunflower $\mathrm{x}$ Xaraes palisadegrass & $71.83 \mathrm{ABb}$ & $99.50 \mathrm{Aba}$ \\
\hline $\mathrm{CV} \%$ & & \\
\hline
\end{tabular}

Continue... 
Continuation...

\begin{tabular}{lcc}
\hline & \multicolumn{2}{c}{ Plant height harvest DAE (cm) } \\
Marandu palisadegrass in monoculture & $80.63 \mathrm{Aa}$ & $109.50 \mathrm{Ab}$ \\
Piata palisadegrass in monoculture & $90.16 \mathrm{Aa}$ & $112.90 \mathrm{Ab}$ \\
Xaraes palisadegrass in monoculture & $100.33 \mathrm{Aa}$ & $135.96 \mathrm{Ab}$ \\
Sunflower x Marandu palisadegrass & $61.36 \mathrm{Ba}$ & $78.10 \mathrm{Bb}$ \\
Sunflower x Piata palisadegrass & $59.06 \mathrm{Ba}$ & $76.83 \mathrm{Bb}$ \\
Sunflower x Xaraes palisadegrass & $85.80 \mathrm{Aa}$ & $101.50 \mathrm{ABb}$ \\
CV\% & & \\
\hline
\end{tabular}

Means followed by different upper case letters in the same column (forage systems) and lower case letters in the same row (sowing seasons) are significantly different according to a Tukey's test, at $p<0.05$.

Dry weight production was not different ( $>0.05$ ) between the $B$. brizantha cultivars grown in monoculture and the Xaraes palisadegrass cultivar grown with intercropping during either sowing season (Table 7). This was attributed to the morphology of the Xaraes palisadegrass cultivar, which has wide leaves, fast growth and high dry weight production (FLORES et al., 2008), causing suppression of sunflower development and similar dry weights under intercropping and monoculture. However, the Marandu palisadegrass and Piata palisadegrass cultivars had lower dry weight production with intercropping, due to suppression by sunflower plants. This indicates that these Brachiaria brizantha cultivars do not tolerate shading from sunflower plants, resulting in low forage production. This is in accordance with Gontijo Neto et al. (2009), who observed that sunflowers caused a decrease in forage production by $B$. brizantha cv. Xaraes of approximately $66 \%$ and of $50 \%$ by B. brizantha cv. Piata and Panicum maximum cv. Massai.

Even following the sunflower harvest, the production dry weight (second and third cut) of the Marandu palisadegrass and Piata palisadegrass cultivars was not reestablished due to the low water availability at inter-harvest, which is common in the Center-West region of Brazil. In integrated crop-livestock systems, following sunflower harvest, the area may be used for grazing. The ideal forage plant for intercropping with sunflower has good establishment and growth in intercropping conditions. According to these results, if the main goal is forage production during the inter-harvest, preference should be given to $B$. brizantha cv. Xaraes, because it has higher weight production than the other cultivars.

As previously observed, the sowing season did not influence $(p>0.05)$ the dry weight production of forage systems from the three cuts (Table 7). The second cut exhibited the lowest production, due to the difficulty of resprouting in the absence of rainfall (Figure 1). However, with the beginning of the rainy season in September, there was an improvement in the development of Brachiaria plants, which was reflected in the higher dry weight production. 
Table 7. Mean dry weight production of Brachiaria brizantha cultivars grown in monoculture and in intercropping with sunflower during two different sowing seasons.

\begin{tabular}{|c|c|c|}
\hline \multirow{2}{*}{ Forage systems } & \multicolumn{2}{|c|}{ Sowing seasons } \\
\hline & February & March \\
\hline & \multicolumn{2}{|c|}{ DM production $1^{\text {st }}$ cut - harvest $\left(\mathrm{kg} \mathrm{ha}^{-1}\right)$} \\
\hline Marandu palisadegrass in monoculture & $2.750 \mathrm{Aa}$ & $2.900 \mathrm{Aa}$ \\
\hline Piata palisadegrass in monoculture & $2.605 \mathrm{Aa}$ & $3.105 \mathrm{Aa}$ \\
\hline Xaraes palisadegrass in monoculture & $3.187 \mathrm{Aa}$ & $3.637 \mathrm{Aa}$ \\
\hline Sunflower x Marandu palisadegrass & $1.350 \mathrm{Ba}$ & $1.585 \mathrm{Ba}$ \\
\hline Sunflower $\mathrm{x}$ Piata palisadegrass & $1.265 \mathrm{Ba}$ & $1.515 \mathrm{Ba}$ \\
\hline Sunflower x Xaraes palisadegrass & $3.102 \mathrm{Aa}$ & $3.212 \mathrm{Aa}$ \\
\hline \multirow[t]{2}{*}{$\mathrm{CV} \%$} & \multicolumn{2}{|c|}{19.64} \\
\hline & \multicolumn{2}{|c|}{ DM production $2^{\text {nd }}$ cut $\left(\mathrm{kg} \mathrm{ha}^{-1}\right)$} \\
\hline Marandu palisadegrass in monoculture & $1.148 \mathrm{Aa}$ & $1.368 \mathrm{Aa}$ \\
\hline Piata palisadegrass in monoculture & $1.298 \mathrm{Aa}$ & $1.450 \mathrm{Aa}$ \\
\hline Xaraes palisadegrass in monoculture & $1.602 \mathrm{Aa}$ & $1.650 \mathrm{Aa}$ \\
\hline Sunflower x Marandu palisadegrass & $0.705 \mathrm{Ba}$ & $0.755 \mathrm{Ba}$ \\
\hline Sunflower $\mathrm{x}$ Piata palisadegrass & $0.855 \mathrm{Ba}$ & $0.885 \mathrm{Ba}$ \\
\hline Sunflower x Xaraes palisadegrass & $1.230 \mathrm{Aa}$ & $1.515 \mathrm{Aa}$ \\
\hline \multirow[t]{2}{*}{$\mathrm{CV} \%$} & \multicolumn{2}{|c|}{17.51} \\
\hline & \multicolumn{2}{|c|}{ DM production $3^{\text {rd }}$ cut $\left(\mathrm{kg} \mathrm{ha}^{-1}\right)$} \\
\hline Marandu palisadegrass in monoculture & $2.550 \mathrm{Aa}$ & $2.650 \mathrm{Aa}$ \\
\hline Piata palisadegrass in monoculture & $2.355 \mathrm{Aa}$ & $2.750 \mathrm{Aa}$ \\
\hline Xaraes palisadegrass in monoculture & $3.055 \mathrm{Aa}$ & $3.400 \mathrm{Aa}$ \\
\hline Sunflower x Marandu palisadegrass & $1.975 \mathrm{Ba}$ & $1.950 \mathrm{Ba}$ \\
\hline Sunflower $\mathrm{x}$ Piata palisadegrass & $1.860 \mathrm{Ba}$ & $1.950 \mathrm{Ba}$ \\
\hline Sunflower x Xaraes palisadegrass & $2.253 \mathrm{Aa}$ & $2.900 \mathrm{Aa}$ \\
\hline $\mathrm{CV} \%$ & & \\
\hline
\end{tabular}

Means followed by different upper case letters in the same column (forage systems) and lower case letters in the same row (sowing seasons) are significantly different according to a Tukey's test, at $p<0.05$.

No differences $(\mathrm{p}>0.05)$ in the CP contents were observed between the different forage systems and sowing seasons for the first cut (Table 8). However, for the second and third cut, the Piata palisadegrass cultivar had higher $\mathrm{CP}$ contents than the remaining cultivars tested, both in monoculture and in intercropping with sunflower. This resulted from the higher leaf:stem ratio of this cultivar (NANTES et al., 2013), indicating that it is a good forage plant for use during the inter-harvest. The CP content observed in the second and third cuts were similar to the ones reported by Maia et al. (2014), who evaluated the bromatological composition of forage plants of the genus Brachiaria at the interharvest, following corn harvesting, in integrated crop-livestock systems; they observed a mean of 9.0 and $13.4 \% \mathrm{CP}$ content for September and October, respectively. 
Table 8. Mean crude protein (CP) contents of Brachiaria brizantha cultivars grown in monoculture and in intercropping with sunflower during two different sowing seasons.

\begin{tabular}{|c|c|c|}
\hline \multirow{2}{*}{ Forage systems } & \multicolumn{2}{|c|}{ Sowing seasons } \\
\hline & February & March \\
\hline & \multicolumn{2}{|c|}{ CP contents $-1^{\text {st }}$ cut - harvest $(\%)$} \\
\hline Marandu palisadegrass in monoculture & $7.25 \mathrm{Aa}$ & $7.90 \mathrm{Aa}$ \\
\hline Piata palisadegrass in monoculture & $8.95 \mathrm{Aa}$ & $9.15 \mathrm{Aa}$ \\
\hline Xaraes palisadegrass in monoculture & 7.30 Aa & $7.25 \mathrm{Aa}$ \\
\hline Sunflower x Marandu palisadegrass & $7.50 \mathrm{Aa}$ & $8.50 \mathrm{Aa}$ \\
\hline Sunflower x Piata palisadegrass & $6.75 \mathrm{Aa}$ & $8.75 \mathrm{Aa}$ \\
\hline Sunflower x Xaraes palisadegrass & $7.25 \mathrm{Aa}$ & $8.50 \mathrm{Aa}$ \\
\hline \multirow[t]{2}{*}{$\mathrm{CV} \%$} & \multicolumn{2}{|c|}{7.98} \\
\hline & \multicolumn{2}{|c|}{ CP contents $2^{\text {nd }}$ cut $(\%)$} \\
\hline Marandu palisadegrass in monoculture & $8.50 \mathrm{Ba}$ & $9.05 \mathrm{Ba}$ \\
\hline Piata palisadegrass in monoculture & $11.50 \mathrm{Aa}$ & $12.25 \mathrm{Aa}$ \\
\hline Xaraes palisadegrass in monoculture & $9.10 \mathrm{Ba}$ & $9.75 \mathrm{Ba}$ \\
\hline Sunflower x Marandu palisadegrass & $9.25 \mathrm{Ba}$ & $9.50 \mathrm{Ba}$ \\
\hline Sunflower x Piata palisadegrass & $11.25 \mathrm{Aa}$ & $12.95 \mathrm{Aa}$ \\
\hline Sunflower x Xaraes palisadegrass & $9.25 \mathrm{Ba}$ & $9.85 \mathrm{Ba}$ \\
\hline \multirow[t]{2}{*}{$\mathrm{CV} \%$} & \multicolumn{2}{|c|}{10.79} \\
\hline & \multicolumn{2}{|c|}{ CP contents $3^{\text {rd }}$ cut $(\%)$} \\
\hline Marandu palisadegrass in monoculture & $11.25 \mathrm{Ba}$ & $12.25 \mathrm{Ba}$ \\
\hline Piata palisadegrass in monoculture & $14.10 \mathrm{Aa}$ & $14.75 \mathrm{Aa}$ \\
\hline Xaraes palisadegrass in monoculture & $11.35 \mathrm{Ba}$ & $12.50 \mathrm{Ba}$ \\
\hline Sunflower x Marandu palisadegrass & $11.50 \mathrm{Ba}$ & $11.75 \mathrm{Ba}$ \\
\hline Sunflower x Piata palisadegrass & $13.65 \mathrm{Aa}$ & $13.90 \mathrm{Aa}$ \\
\hline Sunflower x Xaraes palisadegrass & $11.75 \mathrm{Ba}$ & $11.25 \mathrm{Aa}$ \\
\hline $\mathrm{CV} \%$ & & \\
\hline
\end{tabular}

Means followed by different upper case letters in the same column (forage systems) and lower case letters in the same row (sowing seasons) are significantly different according to a Tukey's test, at $p<0.05$.

The NDF contents of the first cut were influenced $(p<0.05)$ by the forage system (Table 9$)$. The lowest NDF contents were observed in the Piata palisadegrass cultivar, both under monoculture and intercropping with sunflower from the February sowing treatment. For the second and third cut, the lowest NDF contents were observed for the Piata palisadegrass cultivar under monoculture, independent of the sowing season. These results are related to the higher proportion of leaves, which contributed to decreased fiber content. The
NDF is essential for the improvement of the forage nutritional value because pastures with higher fiber content occupy the area for longer periods of time and limit the intake rates of animals (LIMA et al., 2002). The observed NDF values were similar to previously reported values for the Marandu palisadegrass cultivar in intercropping with corn (BORGHI et al., 2006; PARIZ et al., 2011).

Lower forage NDFs were observed for the second and third cut compared with the first cut (Table 9). This was due to the high resprouting rate (CHIARI 
et al., 2008) favored by the beginning of the rainy season. This confirms that sunflower intercropping with Brachiaria is an excellent alternative for integrated crop-livestock systems at the interim harvest with the goal of producing quality feed at the inter-harvest.

Table 9. Mean neutral detergent fiber (NDF) contents of Brachiaria brizantha cultivars grown in monoculture and in intercropping with sunflowers in two different sowing seasons.

\begin{tabular}{lcc}
\hline \multirow{2}{*}{ Forage systems } & \multicolumn{2}{c}{ Sowing seasons } \\
\cline { 2 - 3 } & February & March \\
\hline & NDF contents 1 $\mathbf{1}^{\text {st }}$ cut - harvest (\%) \\
Marandu palisadegrass in monoculture & $72.00 \mathrm{Aa}$ & $72.25 \mathrm{Aa}$ \\
Piata palisadegrass in monoculture & $67.75 \mathrm{Ba}$ & $67.05 \mathrm{Ba}$ \\
Xaraes palisadegrass in monoculture & $73.25 \mathrm{Aa}$ & $72.75 \mathrm{Aa}$ \\
Sunflower x Marandu palisadegrass & $72.55 \mathrm{Aa}$ & $72.50 \mathrm{Aa}$ \\
Sunflower x Piata palisadegrass & $67.15 \mathrm{Ba}$ & $67.00 \mathrm{Aa}$ \\
Sunflower x Xaraes palisadegrass & $73.25 \mathrm{Aa}$ & $73.05 \mathrm{Aa}$ \\
CV \% & & 4.52 \\
\hline
\end{tabular}

NDF contents $2^{\text {nd }}$ cut $(\%)$

Marandu palisadegrass in monoculture

$68.00 \mathrm{Aa} \quad 69.50 \mathrm{Aa}$

Piata palisadegrass in monoculture

$64.25 \mathrm{Ba}$

$63.50 \mathrm{Ba}$

Xaraes palisadegrass in monoculture

$69.75 \mathrm{Aa}$

$70.00 \mathrm{Aa}$

Sunflower x Marandu palisadegrass

$70.50 \mathrm{Aa}$

$69.75 \mathrm{Aa}$

Sunflower x Piata palisadegrass

$68.50 \mathrm{Aa}$

$67.80 \mathrm{Aa}$

Sunflower $\mathrm{x}$ Xaraes palisadegrass

$70.50 \mathrm{Aa}$

$70.00 \mathrm{Aa}$

$\mathrm{CV} \%$

4.81

NDF contents $3^{\text {rd }}$ cut $(\%)$

Marandu palisadegrass in monoculture

$68.50 \mathrm{Aa} \quad 67.00 \mathrm{Aa}$

Piata palisadegrass in monoculture

$62.70 \mathrm{Ba}$

$62.25 \mathrm{Ba}$

Xaraes palisadegrass in monoculture

$68.25 \mathrm{Aa}$

$69.15 \mathrm{Aa}$

Sunflower x Marandu palisadegrass

$68.50 \mathrm{Aa}$

$67.25 \mathrm{Aa}$

Sunflower x Piata palisadegrass

$67.50 \mathrm{Aa}$

$66.50 \mathrm{Aa}$

Sunflower $\mathrm{x}$ Xaraes palisadegrass

$69.25 \mathrm{Aa}$

$69.50 \mathrm{Aa}$

$\mathrm{CV} \%$

Means followed by different upper case letters in the same column (forage systems) and lower case letters in the same row (sowing seasons) are significantly different according to a Tukey's test, at $p<0.05$.

No differences $(\mathrm{p}>0.05)$ in $\mathrm{ADF}$ contents were observed for the first cut for all forage systems and sowing seasons (Table 10). However, for the second and third cut, lower ADF contents were observed for the Piata palisadegrass cultivar, both under monoculture and with intercropping.

Starting with the second and third cut, the ADF contents were lower than $40 \%$. This indicates that intercropping $B$. brizantha cultivars with sunflower is a good option for supplying quality feed during the inter-harvest, because after the sunflower harvest, the new tillers emerge, resulting in the production of forage with good digestibility, even during periods when rainfall is not stable. 
Table 10. Mean acid detergent fiber (ADF) contents of Brachiaria brizantha cultivars grown in monoculture and intercropping with sunflower, in two different sowing seasons.

\begin{tabular}{|c|c|c|}
\hline \multirow{2}{*}{ Forage systems } & \multicolumn{2}{|c|}{ Sowing seasons } \\
\hline & Sowing seasons & Sowing seasons \\
\hline & \multicolumn{2}{|c|}{ ADF contents $1^{\text {st }}$ cut - harvest (\%) } \\
\hline Marandu palisadegrass in monoculture & $43.75 \mathrm{Aa}$ & $42.75 \mathrm{Aa}$ \\
\hline Piata palisadegrass in monoculture & $42.75 \mathrm{Aa}$ & $40.25 \mathrm{Aa}$ \\
\hline Xaraes palisadegrass in monoculture & $43.50 \mathrm{Aa}$ & $41.75 \mathrm{Aa}$ \\
\hline Sunflower x Marandu palisadegrass & $43.25 \mathrm{Aa}$ & $41.50 \mathrm{Aa}$ \\
\hline Sunflower x Piata palisadegrass & $42.25 \mathrm{Aa}$ & $40.50 \mathrm{Aa}$ \\
\hline Sunflower $\mathrm{x}$ Xaraes palisadegrass & $42.50 \mathrm{Aa}$ & $42.50 \mathrm{Aa}$ \\
\hline $\mathrm{CV} \%$ & \multicolumn{2}{|c|}{4.60} \\
\hline
\end{tabular}

Marandu palisadegrass in monoculture

ADF contents $2^{\text {nd }}$ cut $(\%)$

Piata palisadegrass in monoculture

$40.25 \mathrm{Aa}$

$40.75 \mathrm{Aa}$

Xaraes palisadegrass in monoculture

$37.00 \mathrm{Ba}$

$36.10 \mathrm{Ba}$

Sunflower x Marandu palisadegrass

$40.75 \mathrm{Aa}$

$41.00 \mathrm{Aa}$

Sunflower $\mathrm{x}$ Piata palisadegrass

$40.50 \mathrm{Aa}$

$40.75 \mathrm{Aa}$

Sunflower $\mathrm{x}$ Xaraes palisadegrass

$37.75 \mathrm{Ba}$

$36.50 \mathrm{Ba}$

CV \%

$40.50 \mathrm{Aa}$

$40.25 \mathrm{Aa}$

3.24

Marandu palisadegrass in monoculture

ADF contents $3^{\text {rd }}$ cut $(\%)$

Piata palisadegrass in monoculture

$39.00 \mathrm{Aa}$

$38.25 \mathrm{Aa}$

Xaraes palisadegrass in monoculture

$35.50 \mathrm{Ba}$

$34.00 \mathrm{Ba}$

Sunflower x Marandu palisadegrass

$40.50 \mathrm{Aa}$

$39.50 \mathrm{Aa}$

Sunflower x Piata palisadegrass

$39.25 \mathrm{Aa}$

$38.25 \mathrm{Aa}$

Sunflower $\mathrm{x}$ Xaraes palisadegrass

$35.00 \mathrm{Ba}$

$33.75 \mathrm{Ba}$

$\mathrm{CV} \%$

$39.25 \mathrm{Aa}$

$39.75 \mathrm{Aa}$

Means followed by different upper case letters in the same column (forage systems) and lower case letters in the same row (sowing seasons) are significantly different according to a Tukey's test, at $p<0.05$.

The Piata cultivar had significantly higher IVDMD than the other forage systems, for all cuts, both under monoculture and with intercropping with sunflower (Table 11). This result was most likely due to the higher CP contents and lower fiber fractions observed for this cultivar. No other significant differences in the IVDMD were observed. Increased digestibility is associated with changes in chemical composition, such as decreased NDF, ADF and hemicellulose contents, which would make readily digestible carbohydrates available to rumen microorganisms (FERNANDES et al., 2002). 
Table 11. Mean in vitro dry mater digestibility (IVDMD) of Brachiaria brizantha cultivars grown in monoculture and in intercropping with sunflowers, in two different sowing seasons.

\begin{tabular}{|c|c|c|}
\hline \multirow{2}{*}{ Forage systems } & \multicolumn{2}{|c|}{ Sowing seasons } \\
\hline & Sowing seasons & Sowing seasons \\
\hline & \multicolumn{2}{|c|}{ IVDMD $1^{\text {st }}$ cut - harvest $(\%)$} \\
\hline Marandu palisadegrass in monoculture & $51.75 \mathrm{Ba}$ & $52.25 \mathrm{Ba}$ \\
\hline Piata palisadegrass in monoculture & $58.25 \mathrm{Aa}$ & $59.50 \mathrm{Aa}$ \\
\hline Xaraes palisadegrass in monoculture & $52.25 \mathrm{Ba}$ & $51.00 \mathrm{Ba}$ \\
\hline Sunflower x Marandu palisadegrass & $51.25 \mathrm{Ba}$ & $51.75 \mathrm{Ba}$ \\
\hline Sunflower x Piata palisadegrass & $57.25 \mathrm{Aa}$ & $58.00 \mathrm{Aa}$ \\
\hline Sunflower x Xaraes palisadegrass & $51.00 \mathrm{Ba}$ & $51.75 \mathrm{Ba}$ \\
\hline \multirow[t]{2}{*}{ CV \% } & \multicolumn{2}{|c|}{3.83} \\
\hline & \multicolumn{2}{|c|}{ IVDMD $2^{\text {nd }}$ cut $(\%)$} \\
\hline Marandu palisadegrass in monoculture & $59.00 \mathrm{Ba}$ & $61.75 \mathrm{Ba}$ \\
\hline Piata palisadegrass in monoculture & $66.75 \mathrm{Aa}$ & $68.25 \mathrm{Aa}$ \\
\hline Xaraes palisadegrass in monoculture & $59.50 \mathrm{Ba}$ & $61.75 \mathrm{Ba}$ \\
\hline Sunflower x Marandu palisadegrass & $60.50 \mathrm{Ba}$ & $60.25 \mathrm{Ba}$ \\
\hline Sunflower x Piata palisadegrass & $66.00 \mathrm{Aa}$ & $68.00 \mathrm{Aa}$ \\
\hline Sunflower x Xaraes palisadegrass & $61.25 \mathrm{Ba}$ & $62.25 \mathrm{Ba}$ \\
\hline \multirow[t]{2}{*}{$\mathrm{CV} \%$} & \multicolumn{2}{|c|}{4.22} \\
\hline & \multicolumn{2}{|c|}{ IVDMD $3^{\text {rd }}$ cut (\%) } \\
\hline Marandu palisadegrass in monoculture & $62.50 \mathrm{Ba}$ & $63.00 \mathrm{Ba}$ \\
\hline Piata palisadegrass in monoculture & $69.50 \mathrm{Aa}$ & $69.00 \mathrm{Aa}$ \\
\hline Xaraes palisadegrass in monoculture & $63.75 \mathrm{Ba}$ & $63.50 \mathrm{Ba}$ \\
\hline Sunflower x Marandu palisadegrass & $62.00 \mathrm{Ba}$ & $62.50 \mathrm{Ba}$ \\
\hline Sunflower x Piata palisadegrass & $70.25 \mathrm{Aa}$ & $68.75 \mathrm{Aa}$ \\
\hline Sunflower x Xaraes palisadegrass & $62.75 \mathrm{Ba}$ & $60.75 \mathrm{Ba}$ \\
\hline $\mathrm{CV} \%$ & \multicolumn{2}{|c|}{6.56} \\
\hline
\end{tabular}

Means followed by different upper case letters in the same column (forage systems) and lower case letters in the same row (sowing seasons) are significantly different according to a Tukey's test, at $p<0.05$.

\section{Conclusions}

Intercropping of sunflower with $B$. brizantha cv. Xaraes negatively affected the agronomic characteristics of sunflower. The Marandu palisadegrass and Piata palisadegrass cultivars are therefore recommended for intercropping with sunflower.

B. brizantha cv. Xaraes is most indicated for forage production, and $B$. brizantha $\mathrm{cv}$. Piata is most indicated for the production of forage with a higher nutritional value.

Sowing in March resulted in better sunflower cultivation in the intercropping results, with no effect on the productive and nutritional characteristics of the forage.

The intercropping of sunflower with $B$. brizantha cultivars in the interim harvest was found to be a promising cultivation method for achene and forage production at the inter-harvest in the Center-West region of Brazil. 


\section{References}

BACKES, L. R.; SOUZA, A. M.; BALBINOT JUNIOR, A. A.; GAllotTi, G. J. M.; BAVARESCO, A. Desempenho de cultivares de girassol em duas épocas de plantio de safrinha no planalto norte catarinense, Scientia Agraria, Curitiba, v. 9, n. 1, p. 41-48, 2008.

BISCARO, G. A.; MACHADO, J. R.; TOSTA, M. S.; MENDONÇA, V.; SORATTO, R. P.; CARVALHO, L. A. Adubação nitrogenada em cobertura no girassol irrigado nas condições de Cassilândia-MS. Ciência $e$ Agrotecnologia, Lavras, v. 32, n. 5, p. 1366-1373, 2008.

BORGHI, E.; CRUSCIOLI, C. A. C.; COSTA, C.; MATEUS, G. P. Produtividade e qualidade das forragens de milho e de Brachiaria brizantha em sistema de cultivo consorciado. Revista Brasileira de Milho e Sorgo, Sete Lagoas, v. 5, n. 3, p. 369-381, 2006.

CAPONE, A.; BARROS, H. B.; SANTOS, E. R.; SANTOS, A. F.; FERRAZ, E. C.; FIDELIS, R. R. Épocas de semeadura de girassol safrinha após milho, em plantio direto no Cerrado Tocantinense. Revista Brasileira de Ciências Agrárias, Recife, v. 6, n. 3, p. 460-466, 2011.

CASTRO, C.; FARIAS, J. R. B. Ecofisiologia do girassol. In: LEITE, R. M. V. B.; BRIGHENTI, A. M.; CASTRO, C. (Ed.). Girassol no Brasil. Londrina: Embrapa Soja, 2005. p. 163-218.

CHIARI, L.; ROCHA, M.; VALLE, C. B.; SALGADO, L. R. Variabilidade genética em acessos e cultivares de quatro espécies de Brachiaria estimada por marcadores RAPD. Campo Grande, MS: Embrapa Gado de Corte, 2008. 20 p. (Boletim de Pesquisa e Desenvolvimento, 24).

COMPANHIA NACIONAL DE ABASTECIMENTO CONAB. Levantamento da safra 2013/2014. v.1, n.12. Brasília: Conab, 2014. Disponível em: <www.conab.gov. br>. Acesso em: 6 nov. 2014.

COSTA, R. R. G. F.; COSTA, K. A. P.; SANTOS, C. B.; SEVERIANO, E. C.; EPIFANIO, P. S.; SILVA, J. T.; TEIXEIRA, D. A. A.; SILVA, V. R. Production and nutritional characteristics of peral millet and Paiaguas palisadegrass under different forage systenms and sowing periods in the offseason. African Journal of Agricultural Research, Ebène, v. 11, n. 19, p. 1712-1723, 2016.

FERNANDES, L. D. O.; REIS, R. A.; RODRIGUES, L. R. D. A.; LEDIC, I. L.; MANZAN, R. J. Quality of Ammoniated Brachiaria decumbens Hay. Revista Brasileira de Zootecnia, Viçosa, MG, v. 31, n. 3, p. 13251332, 2002.

FERREIRA, D. F. Sisvar: a computer statistical analysis system. Ciência e Agrotecnologia, Lavras, v. 35, n. 6, p.
1039-1042, 2011.

FLORES, R. S.; EUCLIDES, V. P. B.; ABRÃO, M. P. C.; GALBEIRO, S.; DIFANTE, G. S.; BARBOSA, R. A. Desempenho animal, produção de forragem e características estruturais dos capins marandu e xaraés submetidos a intensidades de pastejo. Revista Brasileira de Zootecnia, Viçosa, MG, v. 37, n. 8, p. 1355-1365, 2008.

GAMA, P. E.; GIL, R. A. S. S.; LACHTER, E. R. Produção de biodiesel através de transesterificação in situ de sementes de girassol via catálise homogênea e heterogênea. Química Nova, São Paulo, v. 33, n. 9, p. 1859-1862, 2010.

GOMES, E. P.; ÁVILA, M. R.; RICKLI, M. E.; PETRI, F.; FEDRI, G. Desenvolvimento e produtividade do girassol sob lâminas de irrigação em semeadura direta na região do Arenito Caiuá, Estado do Paraná. Irriga, Botucatu, v. 15, n. 4, p. 373-385, 2010.

GONTIJO NETO, M. M.; LEITE, C. E. P.; UBA, M. A.; VASCONCELOS, F. V.; PEREIRA FILHO, I. A.; CRUZ, J. C. Avaliação de girassol e forrageiras tropicais perenes em cultivo consorciado. Sete Lagoas: Editora Embrapa Milho e Sorgo, 2009, 16 p. (Boletim de Pesquisa e Desenvolvimento / Embrapa Milho e Sorgo).

KARADOOAN, T.; AKGÜN, Í. Effect of leaf removal on sunflower yield and yield components and some quality characters. Helia, Novi Sad., v. 32, n. 50, p. 123$134,2009$.

LIMA JÚNIOR, I. S.; BERTONCELLO, T. F.; MELO, E. P.; DEGRANDE, P. E.; KODAMA, C. Desfolha artificial simulando danos de pragas na cultura do girassol (Helianthus annuus L., Asteraceae). Revista Ceres, Viçosa, MG, v. 57, n. 1, p. 23-27, 2010.

LIMA, L. G.; NUSSIO, L. G. N.; GONÇALVES, J. R. S.; SIMAS, J. M. C.; PIRES, A. V.; SANTOS, F. A. P. Fontes de amido e proteína para vacas leiteiras em dietas à base de capim-elefante. Scientia Agricola, São Paulo, v. 59, n. 1, p. 19-27, 2002.

LOBO, T. F.; GRASSI FILHO, H.; COELHO, H. A. Efeito da adubação nitrogenada na produtividade do girassol. Científica, Jaboticabal, v. 40, n. 1, p. 59-68, 2012.

MAIA, G. A.; COSTA, K. A. P.; SEVERIANO, E. C.; EPIFANIO, P. S.; FLÁVIO NETO, J.; RIBEIRO, M. G.; FERNANDES, P. B.; SILVA, J. F. G.; GONÇALVES, W. G. Yield and chemical composition of Brachiaria forage grasses in the offseason after corn harvest. American Journal of Plant Sciences, Uzbekistan, n. 5, p. 933-941, 2014. 
NANTES, N. N.; EUCLIDES, V. P. B.; MONTAGNER, D. B.; LEMPP, B.; BARBOSA, R. A.; GOIS, P. O. Desempenho animal e características de pastos de capimpiatã submetidos a diferentes intensidades de pastejo. Pesquisa Agropecuária Brasileira, Brasília, v. 48, n. 1, p. 114-121, 2013.

PARIZ, C. M.; ANDREOTTI, M.; BERGAMASCHINE, A. F.; BUZETTI, S.; COSTA, N. R.; CAVALLINI, M. C. Produção, composição bromatológica e índice de clorofila de braquiárias após o consórcio com milho. Archivos de Zootecnia, Córdova, v. 60, n. 232, p. 10411052, 2011.

SANTOS, A. C.; ANDRADE, A. P.; LIMA, J. R. S.; SILVA, I. F.; CAVALCANTE, V. R. Variabilidade temporal da precipitação pluvial: nível de nitrogênio no solo e produtividade de cultivares de girassol. Ciência Rural, Santa Maria, v. 32, n. 5, p. 757-764, 2002.

SANTOS, C. B.; COSTA, K. A. P.; OLIVEIRA, I. P.; SEVERIANO, E. C.; COSTA, R. R. G. F.; SILVA, A. G.; GUARNIERI, A.; SILVA, J. T. Production and nutritional characteristics of sunflowers and paiaguas palisadegrass under different forage systems in the off season. Biosciense Journal, Uberlândia, v. 32, n. 2, p. 460-470, 2016.

SANTOS, E. R.; BARROS, H. B.; CAPONE, A.; FERRAZ, E. C.; FIDELIS, R. R. Efeito de épocas de semeadura sobre cultivares de girassol, no Sul do Estado do Tocantins. Revista Ciência Agronômica, Fortaleza, v. 43, n. 1, p. 199-206, 2012.

SILVA, D. J.; QUEIROZ, A. C. Análise de alimentos: métodos químicos e biológicos. 3. ed. Viçosa, MG: Imprensa Universitária da UFV, 2002. 235 p.

SILVA, M. L. O.; FARIA, M. A.; MORAIS, A. R.; ANDRADE, G. P.; LIMA, E. M. C. Crescimento e produtividade do girassol cultivado na entressafra com diferentes lâminas de água. Revista Brasileira de Engenharia Agrícola e Ambiental, Campina Grande, v. 11, n. 5, p. 482-488, 2007.
SOUSA, D. M. G.; LOBATO, E. (Ed.). Cerrado: correção do solo e adubação. Planaltina: Embrapa Cerrados, 2002. $416 \mathrm{p}$.

SOUZA, F. R.; SILVA, I. M.; PELLIN, D. M. P.; BERGAMIN, A. C.; SILVA, R. P. Características agronômicas do cultivo de girassol consorciado com Brachiaria ruziziensis. Revista Ciência Agronômica, Fortaleza, v. 46, n. 1, p. 110-116, 2015.

SOUZA, L. H. B.; PEIXOTO, C. P.; SILVEIRA, P. S.; LEDO, C. A. S.; SANTOS, V. P.; SANTOS, A. P. S. G. Características agronômicas e rendimento de girassol em diferentes épocas de semeadura e populações de plantas no Recôncavo da Bahia. Bioscience Journal, Uberlândia, v. 30, p. 90-100, 2014. Suplemento 1.

TILLEY, J. M. A.; TERRY, R. A. A two stage technique for in vitro digestion of forages crops. Journal of the British Grassland Society, Britannia, v. 18, n. 2, p. $104-$ 111, 1963.

TOMICH, T. R.; RODRIGUES, J. A. S.; GONÇALVES, L. C.; TOMICH, R. G. P.; CARVALHO, A. U. Potencial forrageiro de cultivares de girassol produzidos na safrinha para ensilagem. Arquivo Brasileiro de Medicina Veterinária e Zootecnia, Belo Horizonte, v. 55, n. 6, p. 756-762, 2003.

TORRES, J. L. R.; PEREIRA, M. G.; FABIAN, A. J. Produção de fitomassa por plantas de cobertura e mineralização de seus resíduos em plantio direto. Pesquisa Agropecuária Brasileira, Brasília, v. 43, n. 3, p. 421-428, 2008.

UCHÔA, S. C. P.; IVANOFF, M. E. A.; ALVES, J. M. A.; SEDIYAMA, T.; MARTINS, S. A. Adubação de potássio em cobertura nos componentes de produção de cultivares de girassol. Revista Ciência Agronômica, Fortaleza, v. 42, n. 1, p. 8-15, 2011. 
